\title{
Comparison of detrital zircon U-Pb ages between sandy and fine-grained sediments in the East China Sea:Implications for understanding source-to-sink processes in the continental margin sea
}

Xiangtong Huang ${ }^{1}$, HaOXIANG Yang ${ }^{1}$, JiAZE SONG ${ }^{1}$, ERGANG LIAN ${ }^{1}$, SHOUYE YANG ${ }^{1}$

${ }^{1}$ State Key Laborotary of Marine Geology, Tongji University, Shanghai, 200092, People's Republic of China

The East China Sea (ECS) is one of the biggest continental margin seas in the world, with sediments being derived from various sources including large rivers like the Yangtze and the Yellow River and numerous small mountainous rivers in SE China and Taiwan Island. The sediments on the seafloor are in general characterised in general by sandy and fine-grained ones. Despite that the sediment sources of the fine-grained sediment have been well-studied in the last two decades using the methods of clay minerals, geochemistry and isotopes, it is still less known for thoes of sandy sediments in part due to the grain-size effects on the forementioned rountine methods. In contrast, detrizal zircon $\mathrm{U}-\mathrm{Pb}$ ages has been widely used to study provenance of sandy sediments due to no or minor grain-size effects but few studies have been applied to fine sediments as to difficulties in mineral separation and concerns on analytical precison.

In this present, we will compare the detrital zircon $\mathrm{U}-\mathrm{Pb}$ ages from different grain-sized sediments in the ECS, including the muddy belts in the inner continental shelf, sandy/silty sediments in the middle to outer shelfs. We would like to address a few quesitons that might be helpful to understand sediment source-to-sink processes in the contiental margin sea, which include that 1) whether the detrital zircon ages are impacted by grain-size effects, 2) whether there are provenance similarities or dissimilarities among different sediments and 3) what the roles are played by oceanic hydrodynimcs (current, tide and waves) in sediment transport and $\mathrm{U}-\mathrm{Pb}$ age distributions. 